\title{
Borate single crystals for polyfunctional applications: production and properties
}

\author{
B.V. Grinyov, M.F. Dubovik, A.V. Tolmachev \\ Institute for Single Crystals, NAS Ukraine, 60 prospekt Lenina, Kharkiv, 61001, Ukraine \\ avtol@isc.kharkov.com.
}

\begin{abstract}
Literature data and results of authors' studies are rewieved concerning structure, growing conditions, non-linear optical, piezoelectric and spectral characteristics of borate single crystals $\mathrm{Li}_{2} \mathrm{~B}_{4} \mathrm{O}_{7}, \mathrm{LiB}_{3} \mathrm{O}_{5}, \beta-\mathrm{BaB}_{2} \mathrm{O}_{4}, \mathrm{LaB}_{3} \mathrm{O}_{6}, \mathrm{Li}_{6} \mathrm{Gd}\left(\mathrm{BO}_{3}\right)_{3}$. A high scintillation efficiency of $\mathrm{LaB}_{3} \mathrm{O}_{6}$ and $\mathrm{Li}_{6} \mathrm{Gd}\left(\mathrm{BO}_{3}\right)_{3}:$ Ce single crystals as well as the high thermostimulated luminescence yield of $\mathrm{Li}_{2} \mathrm{~B}_{4} \mathrm{O}_{7}$ : $(\mathrm{Ce}, \mathrm{Eu}, \mathrm{Tm})$ ones have been demonstrated.
\end{abstract}

Keywords: single crystal, borates, growing, Czochralski method, structure, absorption, luminescence, activator.

Paper received 26.06.00; revised manuscript received 30.06.00; accepted for publication 12.07.00.

\section{Introduction}

Borate single crystals are today under intense study by many researchers as new materials for non-linear optics, acoustoelectronics, piezotechnique and dosimetry. In this work, an attempt is made to review the research results concerning the main physical and physico-technical properties of most effective borate single crystals from the standpoint of perspectives of their practical use.

It was just lithium tetraborate $\mathrm{Li}_{2} \mathrm{~B}_{4} \mathrm{O}_{7}$ (LTB) first synthesized in England [1] that was under the first borates in development. Its practical importance consists in that its piezoelectrical parameters exceed those of quartz and the temperature coefficient of frequency (TCF) is zero in the room temperature range, thus defining its use in filters for surface acoustic waves (SAW) and resonators of bulk ones (BAW) [2-4]. Moreover, the LTB ctystal is a superionic conductor [5]. Later, this crystal has been found to be of promise in the scintillation engineering field [6-8]. Copper-activated LTB crystal is described as an efficient material for high-temperature dosimetry $[9$, 10]. Single crystals of LTB doped with rare-earth elements have been obtained providing an improved thermostimulated luminescence (TSL) yield [11].

Further researches have been resulted in the discovery of a high non-linear optical efficiency of barium borate $\mathrm{BaB}_{2} \mathrm{O}_{4}$ crystals ( $\mathrm{BBO}, \beta$-modification) [12] and in lithium triborate $\mathrm{LiB}_{3} \mathrm{O}_{5}$ (LBO) ones $[13,14]$ showing also a high resistance against laser radiation with the wavelength $\lambda=1.064 \mu \mathrm{m}$.
Another effect of importance has been realized in borate single crystals, namely, the non-linear optical transformation of the laser radiation at $\lambda=1.064 \mu \mathrm{m}$ into second harmonics at an efficiency up to $30 \%$ in the exciting beam direction. This was attained first using $\operatorname{AlY}\left(\mathrm{BO}_{3}\right)$ crystals $[15,16]$ and $\mathrm{LaBGeO}_{5}$ ones $[17,18]$. Recently, $\mathrm{Ln}_{2} \mathrm{Ca}_{3}\left(\mathrm{BO}_{3}\right)_{4}$ ( $\left.\mathrm{Ln}=\mathrm{Y}, \mathrm{La}, \mathrm{Gd}\right)$ [19] and $(\mathrm{Ln}: \mathrm{Sc})_{4-\mathrm{x}} \mathrm{Ce}_{\mathrm{x}}\left(\mathrm{BO}_{3}\right)_{4}(\mathrm{Ln}=\mathrm{Nd}, \mathrm{Pr}, \mathrm{Er}-\mathrm{Yb})[20]$ crystals have been found to be of promise for that purpose.

Materials with good prospects in scintillation engineering and dosimetry of radiation and corpuscular fluxes have been found among borate compounds. These include, besides of above-mentioned LTB, InBO:Tb [21], $\mathrm{LaB}_{3} \mathrm{O}_{6}, \mathrm{LaMgB}_{5} \mathrm{O}_{10}$ and $\mathrm{Li}_{6} \mathrm{Gd}\left(\mathrm{BO}_{3}\right)_{3}$ [22-24] crystals doped with cerium and other rare-earth ions.

\section{Specific structure features of borate com- pounds}

About $65 \%$ of known borate compounds have crystallochemical structures characterized by $\mathrm{BO}_{3}$ triangles which are either isolated or joined with each other. Such anionic units form ionic bonds with metal cations. Such structures are typical for ortho-, pyro-, and methaborates. About $50 \%$ of borate compounds exhibit crystal structure including polyanion $\left(\mathrm{B}_{\mathrm{n}} \mathrm{O}_{\mathrm{m}}\right)$. In polyborates, the triangles are joined both with each other and with tetrahedrons by the common oxygen atom. In the latter case, the number of possible combinations is very large. Fig. 1 


\section{B.V. Grinyov et al.: Borate single crystals for polyfunctional applications ...}<smiles>OC(O)O</smiles>

$\left(\mathrm{B}_{2} \mathrm{O}_{5}\right)^{4-}$
PYRO-

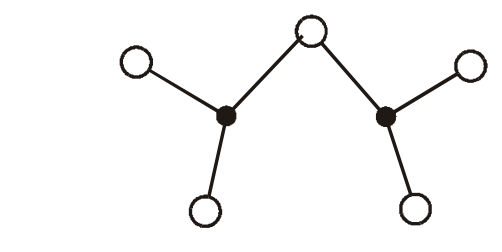

$(\mathrm{BO})^{3-}$

ORTHO-

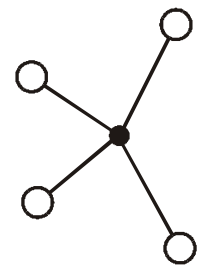

$\left(\mathrm{BO}_{2}\right)^{1-}$

META-
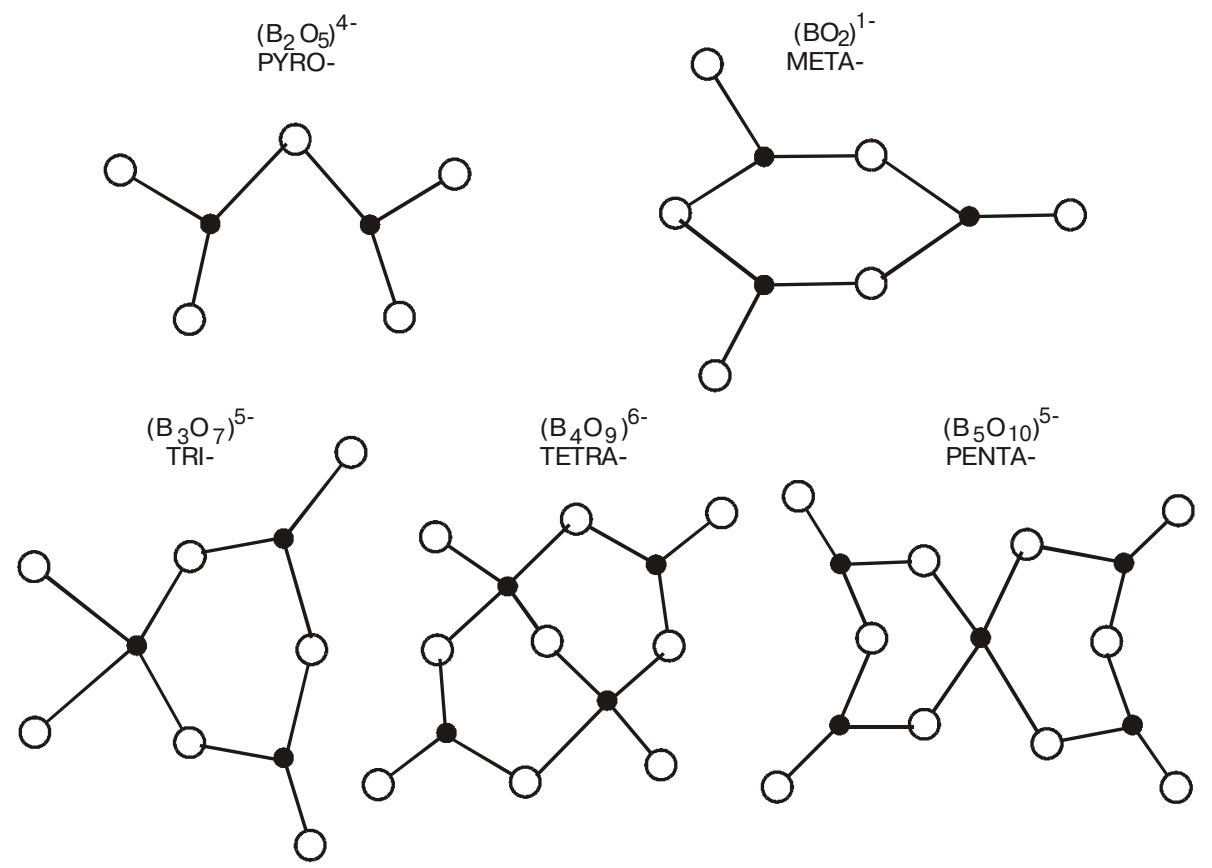

Fig.1. Fragment of boron-oxide compound structure.

presents some variations of triangles and tetrahedrons combinations in tri-, tetra-, and pentaborates [25].

Consideration of data available from Bonn data bank on inorganic structures (ICSD) as well as of literature data on structures of alkali, alkali-earth and rare-earth borates has shown that about 30 compounds have noncentrally symmetric unit cell structure. This feature defines the specific properties of most of borate crystals now in use, both non-linear optical (LBO, BBO) and acousto-optical (LTB) ones.

It is just the rigid polymeric boron-oxygen skeleton having voids where $\mathrm{Li}^{+}$cations are positioned that defines the crystal lattice of alkali borates, e.g., of lithium tetraborate LTB, [26-28]. In rare-earth borates, it is just coordination polyhedrons of heavy polyvalent cations that form the structure base. The anionic sublattice is in this case of no significant importance. So, in lithiumgadolinium borate, the crystal structure consists of $\mathrm{Li}$ and $\mathrm{Gd}$ polyhedrons linked into a three-dimensional mixed skeleton by island $\mathrm{BO}_{3}$ triangles. Alkali-earth metal borates (barium beta-borate $\mathrm{BaB}_{2} \mathrm{O}_{4}$ [29]) and some rareearth metal borates (e.g., lanthanum methaborate $\mathrm{LaB}_{3} \mathrm{O}_{6}$ [30]) form structures including a polymeric skeleton consisting of two-dimensional boron-oxygen complexes joined together with metal cations by ionic bonds with nearest $\mathrm{O}^{2-}$ ions.
A large number of boron atoms per unit cell $\left({ }^{10} \mathrm{~B}\right.$ isotope), the presence of $\mathrm{Li}$ atoms ( ${ }^{7} \mathrm{Li}$ isotope) and rareearth elements ones, e.g., gadolinium $\left({ }^{155,157} \mathrm{Gd}\right.$ isotope) allows for the use of borate crystals as a base for inorganic scintillators exhibiting fast-action combined with a high light yield to detect thermal neutrons as well as Xrays and gamma radiation. The directional covalent B$\mathrm{O}$ bond provides a small Stokes shift and a rather high thermal stability of luminescence.

\section{Growing of borate single crystals}

Since borate compounds melt congruently or under decomposition, or exhibit polymorphic phase transitions, their growing methods are to be varied. For example, there are 5 chemical compounds of the $\mathrm{Li}_{2} \mathrm{O}-\mathrm{B}_{2} \mathrm{O}_{3}$ system, and of those, only $\mathrm{LiBO}_{2}$ and $\mathrm{Li}_{2} \mathrm{~B}_{4} \mathrm{O}_{7}$ melt congruently and have no phase transitions within the temperature range from ambient one to the melting point. $\mathrm{LiB}_{3} \mathrm{O}_{5}$ and $\mathrm{InBO}_{3}$ melt under decomposition (at 834 and 1100 ${ }^{\circ} \mathrm{C}$, respectively) [31]. $\mathrm{BaB}_{2} \mathrm{O}_{4}$ exists both in a and $\mathrm{b}$ modifications (the high-temperature phase melts congruently at $1105^{\circ} \mathrm{C}$ and in the course of cooling it becomes transformed into the $\beta$-phase at $925^{\circ} \mathrm{C}$ ). Moreover, the presence of boron-oxygen complexes brings about a tendency to polymerization and causes a high viscosity of the melt. 


\section{B.V. Grinyov et al.: Borate single crystals for polyfunctional application ...}

A stage of importance in the single crystal production is the initial charge synthesis. It is well known [32] that the most widely used method of the charge preparation to grow single crystals of congruently melting compositions is the solid-phase sintering of corresponding oxides or carbonates mixed in stoichiometric ratios. The sintering is performed at pre-melting temperatures for several hours, the synthesized compounds are subjected to repeated grinding operations to improve the homogeneity. The solid-phase method allows to obtain fine-grained mixtures containing up to 95 or $98 \%$ of the main phase. There is also a more simple method of the charge preparation; it is, however, less effective, according to experimental data [33]. This method consists in that initial oxides or carbonates taken in stoichiometric ratio are melted after thorough mixing. To improve the melt homogeneity, it is exposed for several hours prior to growth. In the case when the compound to be used melts non-congruently, the ratio of initial components is selected depending on the flux used, taking into account that the crystal to be grown should have the stoichiometric composition and the specifications for the dopant(s) content should be met.

In most cases, single crystals of compounds melting congruently and exhibiting no polymorphic transformations are grown from the melt using the Czochralski technique [32]. Among borate compounds, $\mathrm{Li}_{2} \mathrm{~B}_{4} \mathrm{O}_{7}$ single crystals are grown by that method [34-36]. According to our experience, the method can be also used to grow $\mathrm{LaB}_{3} \mathrm{O}_{6}$ and $\mathrm{Li}_{6} \mathrm{Gd}\left(\mathrm{BO}_{3}\right)_{3}$ crystals [37-39]. Other types of single crystals under consideration which exhibit polymorphic transformations or non-congruent melting are grown mainly from solutions in melted fluxes (solvents). Boron oxide $\mathrm{B}_{2} \mathrm{O}_{3}$ or other low-melting boron, chlorine, fluorine, etc. Compounds are used as a rule to that end. Two methods of single crystal growing from solution in melt have been studied: (i) spontaneous crystallization and (ii) pulling on a seed under simultaneous lowering of the solution-melt temperature. The second technique is preferred since it allows to grow large-size single crystals [40].

Some data on the growing conditions are presented in the Table 1. Growing conditions for more complex borate crystals mentioned in the introduction (AIBO, LCBO, $\mathrm{L}: \mathrm{SCBO}$, etc.) are now under study.

\section{Properties of most efficient borate single crystals}

\section{Non-linear optical and piezoelectric properties}

Lithium triborate $\mathrm{LiB}_{3} \mathrm{O}_{5}$ (LBO) and barium beta-borate $\mathrm{BaB}_{2} \mathrm{O}_{4}(\mathrm{BBO})$ single crystals are unique non-linear (NL) optical materials. High values of non-linear optical coefficients, wide phase synchronism region, high UV transparency and high radiation resistance are typical for these crystals [46, 47]. Maximum values of non-lin-

Table 1. Growth conditions of some borate crystals.

*- non-centrosymmetrical crystals;

1- original data; 2- [41]; 3- [42]; 4- [43]; 5- [44]; 6- [45]; 7- [18].

\begin{tabular}{|c|c|c|c|c|c|c|c|}
\hline \multirow[t]{2}{*}{ Crystal } & \multirow[t]{2}{*}{ Symmetry } & \multirow[t]{2}{*}{ Melting, $\mathrm{T}^{\circ} \mathrm{C}$} & \multirow[t]{2}{*}{ Growth method } & \multicolumn{3}{|c|}{ Growth conditions } & \multirow{2}{*}{$\begin{array}{c}\begin{array}{c}\text { Crystal size, } \\
\mathrm{d} \times \mathrm{h}, \mathrm{mm}\end{array} \\
30 \times 40^{1}\end{array}$} \\
\hline & & & & $\vartheta_{\text {cool }},{ }^{\circ} \mathrm{C} / \mathrm{h}$ & $\vartheta, \mathrm{mm} / \mathrm{h}$ & $\mathrm{w}, \min ^{-1}$ & \\
\hline $\mathrm{Li}_{2} \mathrm{~B}_{4} \mathrm{O}_{7} *$ & $\mathrm{I} 4_{1} \mathrm{~cd}(4 \mathrm{~mm})$ & $\begin{array}{l}\text { congruently } \\
(917)\end{array}$ & $\begin{array}{c}\text { Czhochralski, } \\
\text { Bridgmen }\end{array}$ & - & $\begin{array}{c}0.5-1 \\
0.3\end{array}$ & $15-25$ & $\begin{array}{c}80 \times 70^{2} \\
82 \times 200^{3}\end{array}$ \\
\hline$\beta-\mathrm{BaB}_{2} \mathrm{O}_{4} *$ & $\mathrm{R} 3(3 \mathrm{~m})$ & $\begin{array}{c}\text { phase transition } \\
\text { (925) }\end{array}$ & $\begin{array}{l}\text { from solution } \\
\text { in melt } \mathrm{Na}_{2} \mathrm{O}\end{array}$ & 0.154 & $0.04-1.5$ & $20-40$ & $5 \times 15^{4}$ \\
\hline $\mathrm{LiB}_{3} \mathrm{O}_{5} *$ & $\begin{array}{l}\text { Pna2 }_{1} \\
\text { (mm2) }\end{array}$ & $\begin{array}{c}\text { noncongruently } \\
\text { (834) }\end{array}$ & $\begin{array}{c}\text { from solution } \\
\text { in melt (spontaneo- } \\
\text { usly and on the seed) }\end{array}$ & $0.008-0.08$ & 0.04 & $<10$ & $35 \times 15^{5}$ \\
\hline $\mathrm{InBO}_{3}$ & R3c & $\begin{array}{c}\text { noncongruently } \\
(1100-1150)\end{array}$ & $\begin{array}{c}\text { Spontaneously } \\
\text { crystallization from } \\
\text { solution } \mathrm{LiBO}_{2}\end{array}$ & 3 & - & - & $\begin{array}{c}\text { Plate } \\
2 \times 2 \times 1^{6}\end{array}$ \\
\hline $\mathrm{LaBGeO}_{5} *$ & $\mathrm{P} 3_{1}$ & $\begin{array}{l}\text { congruently } \\
(1150-1200)\end{array}$ & Czhochralski & - & 1 & $15-25$ & $25 \times 50^{7}$ \\
\hline $\mathrm{LaB}_{3} \mathrm{O}_{6}$ & $\mathrm{C} 2 / \mathrm{c}(2 / \mathrm{m})$ & $\begin{array}{l}\text { congruently } \\
\text { (1141) }\end{array}$ & $\begin{array}{c}\text { from solution in } \\
\text { melt, Czhochralski }\end{array}$ & 0.3 & 0.7 & $15-25$ & $15 \times 8^{1}$ \\
\hline $\mathrm{Li}_{6} \mathrm{Gd}\left(\mathrm{BO}_{3}\right)_{3}$ & $\mathrm{P} 2_{1} / \mathrm{c}(2 / \mathrm{m})$ & $\begin{array}{l}\text { congruently } \\
(850)\end{array}$ & Czhochralski & 20 & 1 & $10-20$ & $20 \times 15^{1}$ \\
\hline
\end{tabular}




\section{B.V. Grinyov et al.: Borate single crystals for polyfunctional applications ...}

earity efficiency in the synchronism direction exceed those for KDP and DKDP non-linear crystals and yield only to KTP. On the other hand, the radiation resistance of borate crystals mentioned is record and exceeds significantly all known NL crystals, including KTP. The radiation resistance of $\mathrm{BBO}$ single crystals is 50 times higher than that of KTP ones while LBO crystals exceed BBO almost twice in that parameter (see Table 2).

LTB single crystals are efficient piezoelectrics and non-ferroelectrics. Extremely high values of piezoelectric coefficients exceeding those of quartz as well as electromechanical coupling coefficient values typical for LTB and exceeding almost 10 times those of quartz allows for its use in acousto-electronics as SAW filters and BAW resonators (Table 3) [48, 49].

\section{X-ray and photoluminescence}

In principle, the detection efficiency must be rather high when borate crystals are under irradiation. Neither neutrons nor $\mathrm{X}$ - and gamma-quanta cause ionization in a direct manner but they loss a fraction of their energy when passing the sample; as a result, charged particles are formed. The beam attenuation follows the law $f=1-e^{-K d}$ where $d$ is the sample thickness; $\mathrm{K}$, absorption coefficient of the specific radiation [50]. It is well known that different interaction processes with a substance take place, depending on the energy of the primary exciting gamma energy: photoeffect, Compton dissipation, electron-positron pair formation and photonuclear reactions [51].

Neglecting the latter probability, let us point to the radiation-stimulated processes in borate crystals that are most efficient in our opinion:

$$
\begin{gathered}
{ }^{10} \mathrm{~B}+\mathrm{n}(6.3 \%){ }^{7} \mathrm{Li}(1.01 \mathrm{MeV})+\alpha(1.78 \mathrm{MeV}) \\
{ }^{10} \mathrm{~B}+\mathrm{n}(93.7 \%){ }^{7} \mathrm{Li}^{*}(0.84 \mathrm{MeV})+\alpha(1.47 \mathrm{MeV}) \\
\downarrow \\
{ }^{7} \mathrm{Li}^{*}(0.84 \mathrm{MeV}) \rightarrow{ }^{7} \mathrm{Li}+\chi(0.48 \mathrm{MeV})
\end{gathered}
$$

Natural abundance of ${ }^{10} \mathrm{~B} 18.5 \%$, thermal neutron capture section of ${ }^{10} \mathrm{~B} \sigma=4010 b$ [52].

${ }^{6} \mathrm{Li}+n \rightarrow{ }^{3} \mathrm{H}(2.75 \mathrm{MeV})+\alpha(2.05 \mathrm{MeV})$

Natural abundance of ${ }^{6} \mathrm{Li} 7.5 \%$, thermal neutron capture section of ${ }^{6} \mathrm{Li} \sigma=945 \mathrm{~b}$. Its advantage is a great amount of energy emitted [53].

\begin{tabular}{|c|c|c|c|c|c|}
\hline Crystal & $\begin{array}{c}\text { Transparent } \\
\text { Waveband, } \\
\mathrm{nm}\end{array}$ & Refractive index & $\begin{array}{l}\text { Damage threshold, } \\
\text { I at } 1064 \mathrm{~nm} \\
\text { radiation }\end{array}$ & $\begin{array}{l}\text { Effective SHG coefficients } \\
\text { in the wavelength } \\
\text { range } 410-3500 \mathrm{~nm}\end{array}$ & $\begin{array}{c}\text { Phase matched } \\
\text { range, } n m\end{array}$ \\
\hline$\beta-\mathrm{BaB}_{2} \mathrm{O}_{4}$ & $190-3500$ & $\begin{array}{c}\lambda=1064 \mathrm{~nm} \\
n_{\mathrm{o}}=1.6545, n_{e}=1.5423, \\
\lambda=532 \mathrm{~nm} \\
n_{\mathrm{o}}=1.6743, n_{e}=1.5549\end{array}$ & $\begin{array}{c}12.9 \mathrm{~J} / \mathrm{cm}^{2} \\
(1.3 \mathrm{~ns})\end{array}$ & $d_{\mathrm{eff}} \mathrm{SHG} / d_{36} \mathrm{KDP}=3.9$ & $0.205-1.5$ \\
\hline $\mathrm{LiB}_{3} \mathrm{O}_{5}$ & $160-3500$ & $\begin{array}{c}\lambda=1064 \mathrm{~nm} \\
n_{x}=1.5656, n_{y}=1.5906 \\
n_{z}=1.6055, \lambda=532 \mathrm{~nm} \\
\mathrm{n}_{\mathrm{x}}=1.5785, n_{y}=1.6065 \\
n_{z}=1.6212\end{array}$ & $\begin{array}{c}24.6 \mathrm{~J} / \mathrm{cm}^{2} \\
(1.3 \mathrm{~ns})\end{array}$ & $d_{\mathrm{eff}} \mathrm{SHG} / d_{36} \mathrm{KDP}=1.5$ & $0.276-1.5$ \\
\hline
\end{tabular}

Table 2. Nonlinear optical properties of $\mathrm{b}-\mathrm{BaB}_{2} \mathrm{O}_{4}$ and $\mathrm{LiB}_{3} \mathrm{O}_{5}$ single crystals [46,47].

$d^{2 w}{ }_{\text {eff }} \mathrm{KDP} \sim d^{2 w}{ }_{\text {eff }} \mathrm{SiO}_{2}=\left[(0.29-0.36) 10^{-12} \mathrm{~m} / \mathrm{V}\right.$ for $\lambda=1064 \mathrm{~nm}$;

$\mathrm{I}\left(\beta-\mathrm{BaB}_{2} \mathrm{O}_{4}\right) / \mathrm{I}(\mathrm{KTP}) \sim 50, \mathrm{I}\left(\mathrm{LiB}_{3} \mathrm{O}_{5}\right) / \mathrm{I}\left(\beta-\mathrm{BaB}_{2} \mathrm{O}_{4}\right) \sim 2,3$

Table 3. Main piezo- and acoustoelectric parameters of $\mathrm{Li}_{2} \mathrm{~B}_{4} \mathrm{O}_{7}$ and $\mathrm{SiO}_{2}$ single crystals $[48,49]$.

\begin{tabular}{cc}
\hline \hline $\mathrm{Li}_{2} \mathrm{~B}_{4} \mathrm{O}_{7}$ single crystal & $\alpha$-quartz single crystal \\
\hline Piezoelectric strain const, $10^{-12} \mathrm{C} / \mathrm{N}$ & Piezoelectric strain const, $10^{-12} \mathrm{C} / \mathrm{N}$ \\
$d_{15}=8.07, d_{31}=-2.58, d_{33}=19.4$ & $d_{11}=2.28, d_{14}=0.85$ \\
\hline Coupling $\mathrm{K}_{\mathrm{s}}{ }^{2}(\mathrm{X}$-cut, Z-propagation - & Coupling K $_{\mathrm{s}}{ }^{2}$ (ST-cut, TSD $\left.=0\right)$ \\
thermostable cut, TSD $=0)$ & $0.15 \%$ \\
$1.2 \%$ & 0 \\
\hline \hline
\end{tabular}




\section{B.V. Grinyov et al.: Borate single crystals for polyfunctional application ...}

${ }^{155} \mathrm{Gd}+n \rightarrow{ }^{156} \mathrm{Gd}+\gamma+$ conversion $e(0.039-0.199 \mathrm{MeV})$

Natural abundance of ${ }^{155} \mathrm{Gd} 15 \%$, thermal neutron capture section of ${ }^{155} \mathrm{Gd} \sigma=17,000 b$.

${ }^{157} \mathrm{Gd}+n \rightarrow{ }^{158} \mathrm{Gd}+\gamma+$ conversion $e(0.029-0.182 \mathrm{MeV})$

Natural abundance of ${ }^{155} \mathrm{Gd} 15 \%$, thermal neutron capture section of ${ }^{157} \mathrm{Gd} \sigma=70,000 b$ [24].

When a neutron is trapped by ${ }^{10} \mathrm{~B}$, a $\gamma$ quantum and an $\alpha$ particle are formed. Thus, this reaction offers the advantage to make it possible to detect the neutron both as the gamma quantum and the $\alpha$ particle. Perhaps the use of ${ }^{6} \mathrm{Li}$ is more preferable, since rather great energy $(43.8 \mathrm{MeV})$ is released at the neutron trapping, that energy is partitioned between the $\alpha$ particle and tritium atom. The interaction of ${ }^{155,157} \mathrm{Gd}$ and with a neutron results in formation of conversion electrons having energies shown in corresponding reaction schemes and gamma quanta. However, the presence in the lattice of isotopes with great neutron capture sections in high concentrations is undesirable, since it results in formation of highenergy isotopes favoring the worsening of the signal-tonoise ratio at the scintillator output.
Original data characterizing the scintillation efficiency of borate compounds are summarized in Table 4. It is just $\mathrm{LaB}_{3} \mathrm{O}_{6}$ and $\mathrm{Li}_{6} \mathrm{Gd}\left(\mathrm{BO}_{3}\right)_{3}: \mathrm{Ce}^{3+}$ crystals exhibiting high light yields that may be of most interest. Due to not too high $Z_{\text {eff }}$ and density values, these crystals can be used in detection of gamma radiation in low and moderate energy ranges (up to about $10 \mathrm{MeV}$ ). Preliminary calculations have shown that absorption coefficients for $\mathrm{LaB}_{3} \mathrm{O}_{6}$ and $\mathrm{Li}_{6} \mathrm{Gd}\left(\mathrm{BO}_{3}\right)_{3}$ in the low and moderate energy range are comparable in the order of magnitude with those of gamma radiation for such traditional scintillation crystals as $\mathrm{NaI}(\mathrm{Tl})$ and $\mathrm{CaWO}_{4}$.

Doping of LTB with rare-earth elements Eu, Ce, Tm does not result in a considerable improvement of light yield in the case of low-energy range irradiation. In contrast, both light yield and dosimetric characteristics become improved significantly when copper is used as the dopant. Thus, the material may be considered as a potential tissue-equivalent scintillator for detection of lowenergy X-rays and gamma radiation. According to preliminary estimations, the light yield of all other compounds is much less than that of $\mathrm{NaI}(\mathrm{Tl})$ crystals.

Table 4. Some characteristics of new boron containing scintillators.

\begin{tabular}{|c|c|c|c|c|c|c|c|c|c|}
\hline \multirow[t]{2}{*}{ Compound } & \multirow[t]{2}{*}{ Dopant } & \multirow{2}{*}{$\begin{array}{c}\text { Emission, } \\
\mathrm{nm}\end{array}$} & \multirow[t]{2}{*}{$\tau, \mathrm{ns}$} & \multirow{2}{*}{$\begin{array}{r}\text { Light yield, } \\
\text { photon/MeV }\end{array}$} & \multicolumn{2}{|l|}{$Z_{\text {eff }}$} & \multirow{2}{*}{$\begin{array}{c}\text { Density, } \\
\mathrm{g} / \mathrm{cm}^{3}\end{array}$} & \multirow{2}{*}{$\begin{array}{c}\text { Effect of } \\
\text { Thermo- } \\
\text { luminescence }\end{array}$} & \multirow[t]{2}{*}{ State } \\
\hline & & & & & Photo & P.P. & & & \\
\hline $\mathrm{LiB}_{3} \mathrm{O}_{5}$ & - & 310 & & & 7.29 & 6.97 & 2.47 & YES & CRYSTAL \\
\hline \multirow[t]{4}{*}{$\mathrm{Li}_{2} \mathrm{~B}_{4} \mathrm{O}_{7}$} & - & 330 & $<2 / 5-6 / 50-100$ & 200 & 7.26 & 7.05 & 2.44 & YES & CRYSTAL \\
\hline & $\mathrm{Ce}$ & 330,360 & & & & & & YES & CRYSTAL \\
\hline & $\mathrm{Eu}$ & $\begin{array}{l}330,589 \\
614,652\end{array}$ & & & & & & YES & CRYSTAL \\
\hline & $\mathrm{Cu}$ & 330,370 & & & & & & YES & CRYSTAL \\
\hline \multirow[t]{2}{*}{$\mathrm{LaB}_{3} \mathrm{O}_{6}$} & - & 342 & & 2000 & 44.5 & 30.9 & 4.18 & YES & CRYSTAL \\
\hline & $\mathrm{Ce}$ & 360 & & & & & & $\mathrm{NO}$ & CRYSTAL \\
\hline $\mathrm{Li}_{6} \mathrm{Gd}\left(\mathrm{BO}_{3}\right)_{3}$ & - & $\begin{array}{l}313 \\
395\end{array}$ & $\begin{array}{l}>\mu \mathrm{s} \\
38\end{array}$ & 17000 & 46.3 & 28.4 & 3.5 & $\begin{array}{l}\mathrm{NO} \\
\mathrm{NO}\end{array}$ & $\begin{array}{l}\text { CRYSTAL } \\
\text { CRYSTAL }\end{array}$ \\
\hline$\beta-\mathrm{Ba}_{2} \mathrm{~B}_{4} \mathrm{O}_{7}$ & $\begin{array}{c}\mathrm{Ce}, \mathrm{Al}, \\
\mathrm{Sr}\end{array}$ & 440 & & & 46.5 & 35.1 & 3.83 & & $\overline{\text { POWDER }}$ \\
\hline $\mathrm{CaBa}_{3} \mathrm{~B}_{8} \mathrm{O}_{16}$ & $\mathrm{Ce}, \mathrm{Na}$ & 440 & & & 43.7 & 30.99 & & & POWDER \\
\hline $\mathrm{SrBa}_{3} \mathrm{~B}_{8} \mathrm{O}_{16}$ & $\mathrm{Ce}, \mathrm{Na}$ & 440 & & & 43.9 & 32.3 & & & POWDER \\
\hline $\mathrm{LaCaB}_{5} \mathrm{O}_{10}$ & $\mathrm{Ce}$ & 420 & & & 38.96 & 24.3 & 4.1 & & GLASS \\
\hline \multirow[t]{4}{*}{$\mathrm{LaMgB}_{5} \mathrm{O}_{10}$} & $\mathrm{Ce}(\gamma)$ & 425 & & & 39.4 & 23.9 & 3.87 & YES & GLASS \\
\hline & $\mathrm{Ce}, \mathrm{Gd}$ & 425 & & & & & & $\mathrm{NO}$ & GLASS \\
\hline & $\operatorname{Pr}$ & 350,600 & $5 \mu \mathrm{s}$ & & & & & YES & GLASS \\
\hline & $\mathrm{Eu}$ & $\begin{array}{c}590,615 \\
700\end{array}$ & & & & & & YES & GLASS \\
\hline
\end{tabular}




\section{B.V. Grinyov et al.: Borate single crystals for polyfunctional applications ...}

A rather comprehensive information on processes responsible for scintillation characteristics can be obtained by studying the photoluminescence and X-ray luminescence spectra, since those data allow to estimate to a certain extent the scintillation efficiency of new materials. Since the scintillation efficiency of undoped LTB crystals is low, those were doped both with rare-earth ions and copper [9-11]. Our preliminary studies have shown, however, that the rare-earth doping does not result in any significant increase of the light yield under X-ray excitation in the range of $30 \mathrm{keV}$, that is, the excitation energy transfer to the activator is ineffective in these conditions. The copper doping causes a considerable increase in the X-ray luminescence intensity near $370 \mathrm{~nm}$. A similar emission region is found at the photoexcitation by $235 \mathrm{~nm}$ wavelength. The nature of that luminescence has not been discussed in detail in literature, but that effect can be supposed to be associated with intracenter transitions in $\mathrm{Cu}^{+}[11]$.

In Fig. 2, X-ray luminescence spectra are presented for undoped and $\mathrm{Ce}^{3+}$ doped $\mathrm{LaB}_{3} \mathrm{O}_{6}$ crystals. It is seen that the X-ray luminescence spectrum of the pure crystal is characterized by a maximum at $342 \mathrm{~nm}$ [37,54]. At present, it is not possible to conclude unambiguously about the nature of this emission but it is likely associated with emissive relaxation of autolocalized excitons that is typical for oxide crystals [55]. The introduction of $\mathrm{Ce}^{3+}$ results in a sharp intensity drop and the luminescence maximum shift towards $360 \mathrm{~nm}$ region [38].

The situation is somewhat different in the case of $\mathrm{Li}_{6} \mathrm{Gd}\left(\mathrm{BO}_{3}\right)_{3}: \mathrm{Ce}^{3+}$ single crystals (Fig. 3) $[39,56]$. In this system, a good overlap exists between emission region of $\mathrm{Gd}^{3+}$ ion ${ }^{6} P_{j}$ transitions and absorption one of $\mathrm{Ce}^{3+}$ ion $4 \mathrm{f}-5 \mathrm{~d}$ transition and, as a result, the excitation energy transfer is efficient. Moreover, Gd is present in the main lattice, thus increasing the density and $Z_{\text {eff }}$ and, respectively, the radiation absorption coefficient. As an X-ray or gamma quantum is absorbed, the formed free carriers cause excitation of $\mathrm{Gd}^{3+}$ ions followed by the excitation

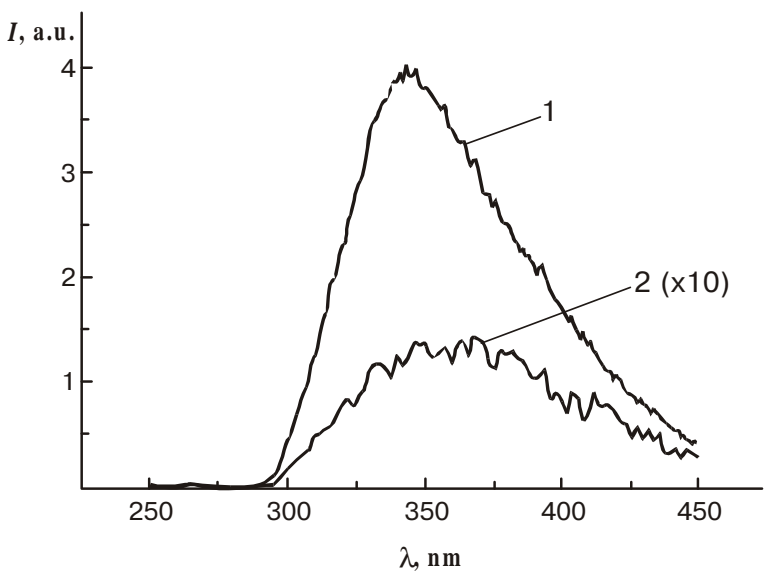

Fig.2. Spectra of X-ray luminescence of: pure $\mathrm{LaB}_{3} \mathrm{O}_{6}(1)$, activated by 0.5 atom $\% \mathrm{Ce}(2)$. energy transfer on to $\mathrm{Ce}^{3+}$ centers through the sublattice. The efficiency of that process is confirmed by experimental data. Under photoluminescence excitation of an undoped crystal in $245-255 \mathrm{~nm}$ and $276 \mathrm{~nm}$ regions corresponding to transitions from the ground ${ }^{8} S_{7 / 2}$ state of $\mathrm{Gd}^{3+}$ ion to excited ${ }^{6} D_{j}$ and ${ }^{6} P_{j}$ ones, respectively, the luminescence with a maximum at $313 \mathrm{~nm}$ was observed caused by the emissive relaxation of ${ }^{6} P_{j}{ }^{-}{ }^{8} S_{7 / 2}$ transitions. When the crystal is doped with cerium, an intence broad band with $395 \mathrm{~nm}$ maximum and characteristic afterglow time $38 \mathrm{~ns}$ appears in the luminescence spectrum; this is due to $4 \mathrm{f}-5 \mathrm{~d}$ transition of $\mathrm{Ce}^{3+}$ ion; moreover, this band is excited in the excitation region of $\mathrm{Gd}^{3+}$ ion luminescence. As Ce concentration increases, the $313 \mathrm{~nm}$ maximum intensity reduces, while that of $395 \mathrm{~nm}$ peak increases.

\section{Thermostimulated luminescence of LTB single crystals}

Maxima on thermoemission curve of undoped crystals correspond to temperature values $365,414,473$, and $538 \mathrm{~K}$ (Fig.4,a). The depth of traps responsible for the TSL peaks is $0.73,0.83,0.95$, and $1.0 \mathrm{eV}$, respectively, as estimated using Urbach method [57]. The induced absorption (IA) spectrum of the undoped sample consists of four individual bands at 235, 285, 321, and $352 \mathrm{~nm}$ wavelengths (Fig. 4,b). The Gaussian maxima are shown by arrows. The same Figure presents IA spectra of LTB after isochronic anneals in temperature range from 340 to $650 \mathrm{~K}$ at $25 \mathrm{k}$ intervals, the exposure time was $5 \mathrm{~min}$. It is seen from comparison of thermostimulated luminescence and thermal bleaching curves of irradiated LTB shown in the Figure that the thermal bleaching occurs in the region of main TSL peaks, thus evidencing that the latter correspond to the certain absorption bands.

To determine the possible localization sites of the trapping centers, irradiated LTB crystals were studied by Xray structure analysis. The occupancy coefficient im-

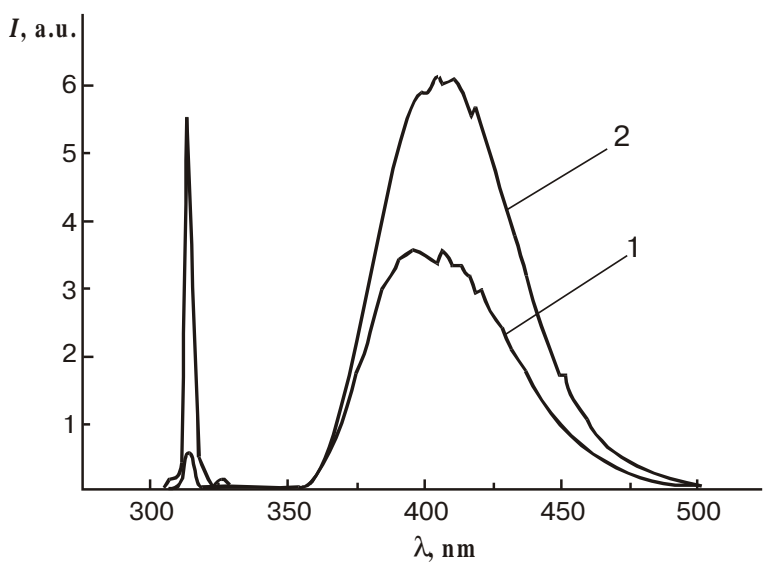

Fig.3. Spectra of X-ray luminescence of $\mathrm{Li}_{6} \mathrm{Gd}\left(\mathrm{BO}_{3}\right)_{3}$ activated by 1 atom $\% \mathrm{Ce}(1), 3$ atom $\% \mathrm{Ce}(2)$. 

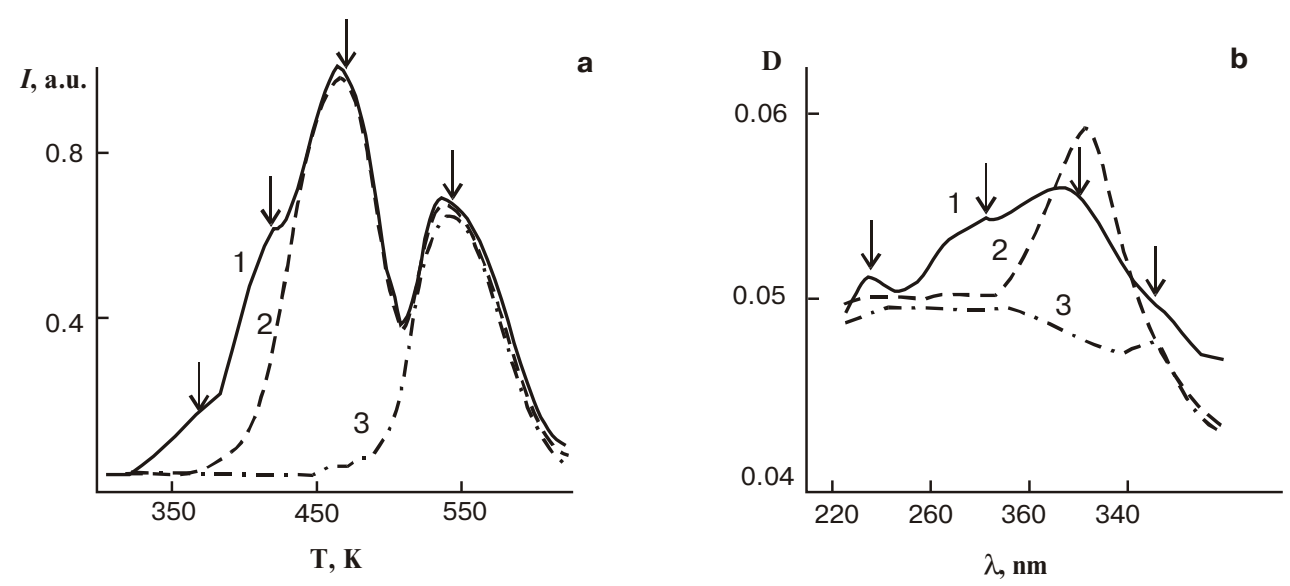

Fig. 4. Thermoluminescence data (a) and absorption (b) of additively colored $\mathrm{Li}_{2} \mathrm{~B}_{4} \mathrm{O}_{7}$ single crystal (non-doped). 1- before thermal annealing, 2- after thermal annealing at $414 \mathrm{~K}, 3-$ after thermal annealing at $630 \mathrm{~K}$. Gaussian maximum is pointed by arrow.

proved by calculation of the irradiated LTB crystal structure shows a deficiency in $\mathrm{Li}, \mathrm{B}(2)$ and $\mathrm{O}(1)$ atoms in their crystallographic positions $\left(K_{\mathrm{Li}}=0.93(2), K_{\mathrm{B}(2)}=0.957(9)\right.$ and $K_{\mathrm{O}(1)}=0.983(5)$.

The absence of $\mathrm{B}(2)$ atoms in their crystallographic positions may be due to boron displacement from the crystal lattice site, e.g., into an interstice, as it has been shown for LBO and LTB crystals [58,59]. In our opinion, the vacancy formation is hindered in this case, since this would require the breaking of too many covalent $\mathrm{B}-\mathrm{O}$ bonds. Li atoms deficiency in their crystallographic position is the greatest as compared to other components of the LTB crystal lattice; perhaps this is due to ionic bonding of Li with anionic LTB sublattice as well as arrangement of its ions in the voids of the dense anionic skeleton. This fact points to the preferred defect formation near those ions. Such a defect, being a negative charged one, can trap a hole and form a hole $\mathrm{O}^{-}$-center [60] that is realized most likely on $\mathrm{O}(1), \mathrm{O}(2)$ and $\mathrm{O}(3)$ atoms nearest to the $\mathrm{Li}^{+}$(Fig. 5).

Since it is just $\left(\mathrm{B}_{4} \mathrm{O}_{9}\right)^{6-}$ clusters that are stable formations in the LTB crystal lattice, atoms $\mathrm{O}(1)$ connecting such structure blocks are strengthened to the least extent, so the irradiation-induced defects should arise most probably in these sites of the anionic sublattice. This supposition is confirmed by the deficiency of $\mathrm{O}(1)$ atoms in their crystallographic positions $\left(K_{\mathrm{O}(1)}=0.983(5)\right.$.It is just the oxygen vacancy that is supposed to be such a radiation-induced defect $[8,59]$. Formation of such a defect in the LTB crystal lattice results in a local excess positive charge arising in the defect site, thus, formation of $\mathrm{F}^{+}$and $\mathrm{F}$ - centers is to be expected.

The additional absorption band with the maximum at $321 \mathrm{~nm}$ can be attributed to the $\mathrm{F}^{+}$-center while that at $352 \mathrm{~nm}$, to the $\mathrm{F}$ - one. The temperature dependence of $321 \mathrm{~nm}$ and $352 \mathrm{~nm}$ band intensity (Fig. 4,b) confirms that both bonds correspond to the same defect in different charge state, namely, to an oxygen vacancy having trapped one electron $\left(\mathrm{F}^{+}\right.$-center $)$and two ones $(\mathrm{F}$-center $)$, respectively. In the region of hole center thermal decomposition, the F-center concentration becomes reduced due to hole trapping by these centers, resulting in an increased number of $\mathrm{F}^{+}$-ones. A similar phenomenon is observed in the $\mathrm{BeO}$ oxide-type crystal [61]. It is known also that the calculated $\mathrm{F}^{+}$-center model in $\mathrm{LiB}_{3} \mathrm{O}_{5}$ crystals must have an absorption band with a maximum at $320 \mathrm{~nm}$ [62] while it is just F-center that is responsible for the absorption band with a maximum near $345 \mathrm{~nm}$ in the irradiated gadolinium-gallium garnet crystal [63]. The absorption bands

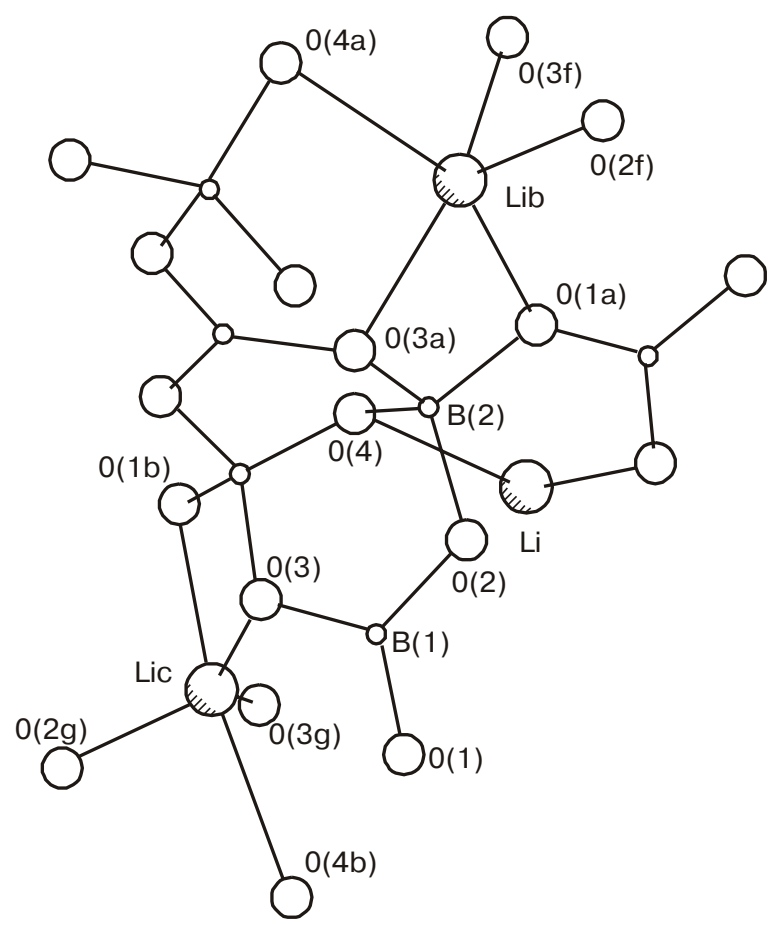

Fig. 5. Structure of $\mathrm{Li}_{2} \mathrm{~B}_{4} \mathrm{O}_{7}(\mathrm{a}=9.479, \mathrm{c}=10.286 \AA$, space group $\left.\mathrm{I} 4_{1} \mathrm{~cd}\right)$. The basic structural unit $\left(\mathrm{B}_{4} \mathrm{O}_{9}\right)$ marked by thick lines. 


\section{B.V. Grinyov et al.: Borate single crystals for polyfunctional applications ...}

at $\lambda=235 \mathrm{~nm}$ and $\lambda=285 \mathrm{~nm}$ are like to be associated with the trapping levels of $\mathrm{O}^{-}$- hole center found before in LBO subjected to electron bombardment and in neutron-irradiated LTB crystals $[59,60]$.

Thus, the combined study of TSL, optical absorption and radiation defects in LTB evidences that thermal emission is due to recombination processes involving the main point defects, namely, oxygen vacancies in $\mathrm{O}(1)$ sites able to trap one or two electrons and, presumably, $\mathrm{O}^{-}$-centers positioned near $\mathrm{Li}^{+}$ion vacancies. The most intense TSL peak is due to the $\mathrm{F}^{+}$-center decay.

To identify the TSL peaks with certain center types as well as to enhance the TSL yield, rare-earth ions $\mathrm{Eu}^{3+}$, $\mathrm{Tm}^{3+}$ and $\mathrm{Ce}^{3+}$ were introduced as dopants into LTB crystals. According to atomic emission spectral analysis, the dopant content in the single crystals was $0.06 \%$ mass. The rare-earth ions may enter the positions of lithium ones, the charge neutrality condition is provided likely due to formation of vacancies in $\mathrm{B}(2)$ ion sites of tetrahedral coordination (the occupancy coefficient $\left.K_{\mathrm{B}(2)}=0.975\right)$. $\mathrm{Eu}^{3+}$ and $\mathrm{Tm}^{3+}$ ions have an electron affinity and favor the formation of hole centers in the crys- tal while, in contrast, the valence state of $\mathrm{Ce}^{3+}$ becomes changed to $\mathrm{Ce}^{4+}$ under irradiation, thus favoring formation of electron trapping centers [64].

The presence of dopants in LTB crystals does not cause appearance of new peaks on the TSL curve (Fig. 6,a). Introduction of $\mathrm{Eu}^{3+}$ results in an increased thermal emission of electron capturing centers at 473 and $538 \mathrm{~K}$. This change in the TSL spectra can be explained by that the state of $\mathrm{Eu}^{2+}$ ion formed when $\mathrm{Eu}^{3+}$ has trapped an electron is metastable, so the captured electron becomes released already at room temperature and then is retrapped by electron traps of the matrix. Activation of $\mathrm{Tm}^{3+}$ causes an increased thermal emission of the hole centers while that of electron centers is suppressed. This can be explained by that electrons generated by the ionizing radiation are trapped by $\mathrm{Tm}^{3+}$ and do not released in the studied temperature range. Introduction of $\mathrm{Ce}^{3+}$ stimulates the emission of electron trapping centers while no hole centers are formed in $\mathrm{Ce}^{3+}$ doped crystal. Electrons generated due to $\mathrm{Ce}^{3+}$ ion irradiation become localized on the electron trapping centers, thus resulting in an increased number of $\mathrm{F}^{+}$- and F-centers (Fig. 6,b). The most intense TSL peak
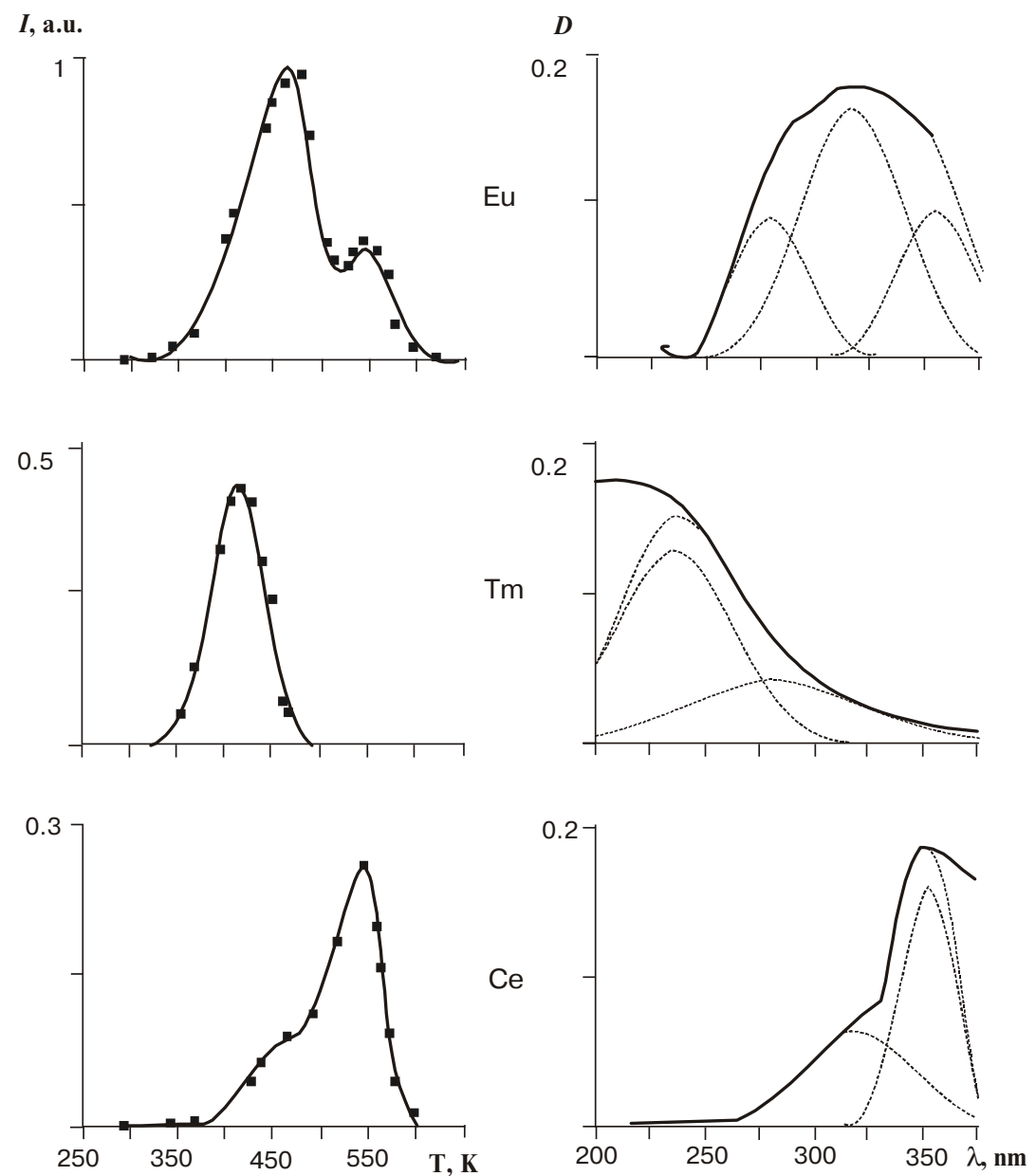

Fig. 6. Thermoluminescence data (a) and absorption (b) of additively colored $\mathrm{Li}_{2} \mathrm{~B}_{4} \mathrm{O}_{7}$ : $\mathrm{Eu}, \mathrm{Li}_{2} \mathrm{~B}_{4} \mathrm{O}_{7}: \mathrm{Tm}, \mathrm{Li}_{2} \mathrm{~B}_{4} \mathrm{O}_{7}$ :Ce single crystals. 


\section{B.V. Grinyov et al.: Borate single crystals for polyfunctional application ...}

is associated with the F-center decay. $\mathrm{Ce}^{3+}$ ion, being a hole acceptor, hinders the formation of hole centers in the matrix. An optical density redistribution between bands with 321 and $352 \mathrm{~nm}$ maxima is observed in IA spectra as compared to those of undoped crystals; this is due to recharging of anionic vacancies.

\section{Conclusion}

Borate single crystals are now objects of intensive research. A record radiation resistance and acceptable values of non-linear optical coefficients of $\mathrm{LiB}_{3} \mathrm{O}_{5}$ and $\beta$ - $\mathrm{BaB}_{2} \mathrm{O}_{4}$ single crystals allow to use those in the nonlinear optics. $\mathrm{Li}_{2} \mathrm{~B}_{4} \mathrm{O}_{7}$ is an effective piezoelectric and non-ferroelectric and thus is a material with good prospects in piezotechniques and acoustoelectronics. A great number of boron atoms $\left({ }^{10} \mathrm{~B}\right.$ isotope) per unit cell allows to use the borate crystals as the base for inorganic scintillators intended for detection of thermal neutrons, $\mathrm{X}$-rays and gamma radiation. The studies performed have shown a high scintillation efficiency of $\mathrm{LaB}_{3} \mathrm{O}_{6}$ and $\mathrm{Li}_{6} \mathrm{GdB}_{3} \mathrm{O}_{6}: \mathrm{Ce}$ single crystals. Since the problem of new scintillation materials offering fast action and high light yield is highly topical at present, it is of interest to study the emission nature of those materials in more detail. The $\mathrm{Li}_{2} \mathrm{~B}_{4} \mathrm{O}_{7}:(\mathrm{Ce}, \mathrm{Eu}, \mathrm{Tm})$ single crystals have shown a high thermostimulated luminescence intensity. The possibility to use those crystals in high-temperature dosimetry is worth of a further consideration.

\section{Acknoledgments}

Authors are thankful to their colleagues, Dr. E.F. Dolzhenkova, Dr. T.I. Korshikova, A.N. Shekhovtsov and L.A. Grin' for their useful assistance in the preparation of this article.

\section{References :}

1. J.D. Garret, M. Natarajan, J.E. Greedan, Growth of $\mathrm{Li}_{2} \mathrm{~B}_{4} \mathrm{O}_{7}$ single crystals // J. Cryst. Growth 41, pp.225-231 (1977).

2. R.W. Wiatmore, N.M. Shorrocks, C. O'Hara et al., Lithium tetraborate: a new temperature-compensated SAW substrate material // Electronics Letters 17(1), pp.11-12 (1981).

3. V.V. Zaretsky, Ya.V. Burak, New non-commensurable crystal (in Russian) // Fiz. Tv. Tela 31(6), pp.80-84 (1989).

4. K.Ya. Borman, Ya.V. Burak, I.T. Perro et al., Preparation and physical properties of lithium tetraborate single crystals (in Russian), in: Actual Problems of Ferroelectric Physics and Chemistr, pp.140-153, Latvian State Univ. Publ., Riga (1987).

5. A.E. Aliev, Ya.V. Burak ,I.T. Lyseyko, Electrophysical properties of the new superionic crystal $\mathrm{Li}_{2} \mathrm{~B}_{4} \mathrm{O}_{7}$ (in Russian) // Neorgan. Mater. 26(9), pp.1991-1993 (1990).

6. E.L. Vinograd, M.B. Kosmyna, A.B. Levin et al., Scintillation parameters of lithium-containing single crystals $\mathrm{Li}_{2} \mathrm{~B}_{4} \mathrm{O}_{7}$ $\mathrm{LiTaO}_{3}, \mathrm{LiNbO}_{3}$ (in Russian) // Funktsionalnye Materialy 1(2), pp.152-154 (1994).

7. Antonyak, Ya.V. Burak, I.T. Luseyko et al., Luminescence of $\mathrm{Li}_{2} \mathrm{~B}_{4} \mathrm{O}_{7}$ crystals (in Russian) // Optika i Spektroskopiya 61(3), pp.550-553 (1986).
8. Ya.V.Burak, B.N.Kopko, I.T.Lyseyko, Colour centers in $\mathrm{Li}_{2} \mathrm{~B}_{4} \mathrm{O}_{7}$ single crystals (in Russian) // Neorgan. Mater. 25(7), pp.1226-1228 (1989).

9. Y. Kutomi, M.H. Kharita, S.A. Durrani, Characteristics of TL and PTTL glow curves of gamma irradiated pure $\mathrm{Li}_{2} \mathrm{~B}_{4} \mathrm{O}_{7}$ single crystals // Radiat. Meas. 24(4), pp.407-410 (1995).

10. Thermoluminescent Materials // Ed. D.R. Vij PRT PrenticeHall, Inc., p.452 (1993)

11. M.F. Dubovik, A.N. Shekhovtsov, L.A. Grin' et al., $\mathrm{Li}_{2} \mathrm{~B}_{4} \mathrm{O}_{7}$ crystals doped with $\mathrm{Eu}$ and $\mathrm{Cu}$ : electrophysical properties and structure // Proc. 1998 IEEE Intern. Freq. Contr. Symposium, May 25-29, 1998. Pasadena, USA, p.766-769.

12. A New Non-Linear Crystal: Inst. for Single Cryst. Information, ONTI (1988).

13. L.K.Chen, New nonlinear optical crystal $\mathrm{LiB}_{3} \mathrm{O}_{5} / /$ J.Opt.Soc.Amer. B6(4), pp.616-621 (1989).

14. L.M.Dorozhkin, I.I.Kuratev, N.I.Leonyuk, The second optical harmonics generation in a new non-linear active medium: neodymium-yttrium-aluminium borate (in Russian) // Pis'ma v Zh. Tekhn. Fiz. 7(21), pp. 1297-1300 (1981).

15. I.S. Girnyk, V.T. Adamiv, Ya.V. Burak, I.M. Teslyuk, Thermal expansion of lithium and barium borates single crystals (in Ukrainian) // Ukr. Fiz. Zh. 44(9), pp.1102-1106 (1999).

16. F. Mougel, Infrared laser performance and self-frequency doubling of $\mathrm{Nd}^{3+}: \mathrm{Ca}_{4} \mathrm{GdO}\left(\mathrm{BO}_{3}\right)_{3} / /$ Optical materials $\mathbf{8}$, pp.161-173 (1997).

17. J. Capmany, L.E. Bause, J. Garsia-Sole, A.A. Kaminskii, $\mathrm{CW}$ end-pumped $\mathrm{Nd}^{3+}: \mathrm{LaBGeO}_{5}$ mini laser for self-frequency-doubling // Program of the ICL'96. Prague, pp.10-45 (1997).

18. E.L. Belokoneva, B.V. Mill, $\mathrm{LaBGeO}_{5}$ polymorphism (in Russian) // Izv. AN SSSR, Ser. Neorgan. Mater. 27(8), pp.1700-1707 (1991).

19. B.V. Mill, A.M. Tkachuk, E.L. Belokoneva, Spectroscopic studies of $\mathrm{Ln}_{2} \mathrm{Ca}_{3} \mathrm{~B}_{4} \mathrm{O}_{12}$ (Ln-Y,La,Gd) crystals // J.of Alloys and Compounds 275-277, pp.291-294 (1998).

20. O.V. Kuzmin, G.M. Kuzmicheva, S.A. Kutovoi et al., Cerium-scandium borate an active nonlinear medium for diode-pumped lasers // Quantum Electronics 28(1), pp.50-54 (1998).

21. J.P. Chaminade, Crystal growth and characterization of $\mathrm{InBO}_{3}: \mathrm{Tb}^{3+} / /$ J. Crystal Growth 99(1-4), pp. 799-804 (1990).

22. G. Blasse, Luminescence materials: is there still news? // J. of Alloys Compounds 225, pp.529-533 (1995).

23. M.J. Knitel, X.E.Yu, Scintillation properties of $\mathrm{Ce}^{3+}$ doped $\mathrm{LaB}_{3} \mathrm{O}_{6} / /$ Proc. SCINT-97. Shanghai: CAS Shanghai Branch Press, pp.318-321 (1997).

24. C.W.E. van Eijk, New scintillators, new light sensors, new applicatuions // Proc. SCINT-97. Shanghai: CAS Shanghai Branch Press, pp.3-12 (1997).

25. N.I. Leonyuk, Structural aspects in crystal growth of anhydrous borates // J. Crystal Growth 174, pp.301-307 (1997).

26. J. Krogh-Moe, The crystal structure of Lithium Diborate, $\mathrm{Li}_{2} \mathrm{O} 2 \mathrm{~B}_{2} \mathrm{O}_{3} / /$ Acta Cryst. 15, pp.190-193 (1962).

27. J. Krogh-Moe, Refinement of the crystal structure of Lithium Diborate, $\mathrm{Li}_{2} \mathrm{O} 2 \mathrm{~B}_{2} \mathrm{O}_{3} / /$ Acta Cryst. B24, pp.179-181 (1962).

28. S.F. Radaev, L.A. Muradyan, L.F. Malakhova, Ya.V. Burak, V.I. Simonov, Atomic structure and electron density of lithium tetraborate (in Russian) // Kristallografiya 34(6), pp.14001407 (1989).

29. D. Eimerl, L. Davis, S. Velsko et al., Optical, mechanical, and thermal properties of barium borate // J. Appl.Phys. 62, pp.1968 (1987).

30. G.K. Abdullaev, H.S. Mamedov, G.G. Dzhafarov, Refined crystal structure of lanthanum metaborate $\mathrm{La}\left(\mathrm{BO}_{2}\right)_{3}$ (in Russian) // Kristallografiya 26(4), pp.837-840 (1989).

31. Chen Chaangtion, The growth of new nonlinear crystals of borate group in China's laboratory // Laser Focus 2, pp.129137 (1989).

32. R. Laudize, R. Parker, The growth of single crystals (in Russian), Moscow: Mir, (1974). 


\section{B.V. Grinyov et al.: Borate single crystals for polyfunctional applications ...}

33. L. Nagornaya, I. Tupitsina, O. Zelenskaya, Influence of admixture defects on scintillation and optical characteristics of cadmium tungstate single crystals // Abstr. of 5th Int. Confer. on Inorganic Scintillators and their Applications. August1620, 1999. Moscow, Russia. P.146.

34. Masatoshi Adachi, Tadashi Shiosaki, Akira Kawabata, Crystal growth of lithium tetraborate $\left(\mathrm{Li}_{2} \mathrm{~B}_{4} \mathrm{O}_{7}\right) / /$ Jap. J.Appl.Phys. 24(Suppl.24-3),pp.72-75 (1985).

35. D.S. Robertson, I.M. Young, The growth and growth mechanism of lithium tetraborate // J. Mater. Science 17, pp.17291738 (1982).

36. B.P. Nazarenko, E.F. Dolzhenkova, A.B. Levin, M.B. Kosmyna, V.F. Tkachenko, Growing lithium tetraborate Monocrystals by Czochralski Method // Functional Materials 1(1), pp. 146-149 (1994).

37. A.N. Shekhovtsov, M.F. Dubovik, A.V.Tolmachev et al., Growth, structure and luminescence of $\mathrm{LaB}_{3} \mathrm{O}_{6}$ single crystals // Abstr. of the Int. Confer. "Advanced Materials". Symposium B. October 3-7, 1999. Kiev, Ukraine, P. 157.

38. A.N.Shekhovtsov, M.F.Dubovik, A.V.Tolmachev et al., Growth and luminescence of $\mathrm{LaB}_{3} \mathrm{O}_{6}$ single crystals: pure and doped by $\mathrm{Ce} / /$ Abstr. of 5th Int. Confer. on Inorganic Scintillators and their Applications. August 16-20, 1999. Moscow, Russia, P. 161

39. A.N.Shekhovtsov, M.F.Dubovik, A.V.Tolmachev, B.V.Grinyov, Growth and luminescence of $\mathrm{Li}_{6} \mathrm{Gd}\left(\mathrm{BO}_{3}\right)_{3}$ single crystals doped by cerium // Abstr. of SPIE's 44th Ann. Meet. and Exhibition, Optical Science, Engineering, and Instrumentation. 18-23 July, 1999. Denver, Colorado USA. P.41.

40. G.V. Lysanova, B.F. Dzhurinsky, M.G. Komova et al., Sinthes and investigation of $\mathrm{LnBGeO}_{5}$ (in Russian) // Izv. AN SSSR. Ser. Neorgan. Mater. 25(4), pp. 632-633 (1989).

41. Fan Shi-ji, Shen Guan-Shun, Wang Wen et al., Bridgmen growth of $\mathrm{Li}_{2} \mathrm{~B}_{4} \mathrm{O}_{7}$ crystals // J. Cryst. Growth 99(1-4), pp.811814 (1990).

42. N.Tsutsui, Y.Ino, K.Imai, N.Senguttuvan, M.Ishii, Growth of large size $\mathrm{LBO}\left(\mathrm{Li}_{2} \mathrm{~B}_{4} \mathrm{O}_{7}\right)$ single crystals by modified Bridgman technigue // J. Cryst. Growth (1999), to be published. Submitted to ACCGE - 11, May 24 (1999).

43. Siang Aidong, Cheng Fen, Lin Qi et al., Flux growth of large single crystals of low temperature phase barium borate // $J$. Cryst.Growth 79, pp.963-969 (1986)

44. Shao Shuging, Huang Chaoen and Zhang Hongwu, Crystal growth and properties of lithium triborate // J.Cryst. Growth 99(1-4), pp.805-810 (1990)

45. J.P. Chaminade, Crystal growth and characterization of $\mathrm{InBO}_{3}: \mathrm{Tb}^{3+} / /$ J.Cryst. Growth 99(1-4), pp.799-804 (1990)

46. M.F. Dubovik, Growing and properties of some oxide single crystals for polyfunctional applications (in Russian) // Izv. AN SSSR Ser. Neorgan. Mater. 28(9), p.p.1999-2006 (1992).

47. T.N. Khartsieva, Lithium triborate - a new perspective nonlinear material (in Russian) // Elektronnaya Tekhnika, Ser. Lasernaya Tekhnika i Optoelektronika 1-2(62-63), pp.76-91 (1990).

48. Tadashi Shiosaki, Masatoshi Adachi, Hiroshi Kobayashi, Kenji Araki, Akira Kawabata, Elastic, piezoelectric, acoustooptic and electro-optic properties of $\mathrm{Li}_{2} \mathrm{~B}_{4} \mathrm{O}_{7} / /$ Jap. J. Appl. Phys. 24 (Suppl.24-1), pp.25-27 (1984).
49. A.E. Aliev, R.R. Valetov, Acoustoionic mechanism of sound absorption in $\mathrm{Li}_{2} \mathrm{~B}_{4} \mathrm{O}_{7}$ (in Russian) // Kristallografiya 36(6), pp. 1507-1515 (1986).

50. J.B. Birks, Scintillation counters, London: Academic Press, pp.2-16 (1953).

51. V.F. Kozlov, Reference Book on Radiation Safety (in Russian), Moscow: Atomizdat, (1977).

52. I. Sharpe, B.Sc, Nuclear radiation measurement, London: Temple Press Ltd, pp.23-32 (1960).

53. W.D. Allen, B. Sc, D. Phil, Neutron detection, London: George Newnes Ltd., pp.25-28 (1960)

54. A.N. Shekhovtsov, M.F. Dubovik, A.V. Tolmachev, B.V. Grinyov, Growth, X-ray, and thermoluminescence of $\mathrm{LaB}_{3} \mathrm{O}_{6}$ single crystals // Abstr. of SPIE's 44th Ann. Meet. and Exhibition, Optical Science, Engineering, and Instrumentation. July 18-23, 1999. Denver, Colorado USA. P.41.

55. A.V. Kuznetsov, V.N. Abramov, B.P. Namozov, T.V. Uibo, Vacuum ultraviolet photoluminescence of $\mathrm{YAlO}_{3}$ (in Russian) // Trudy Instituta Fiziki AN Est. SSR 53, pp. 83-95 (1982).

56. A.N. Shekhovtsov, L.A. Grin', M.F. Dubovik et al., Growth and Luminescence of $\mathrm{LaB}_{3} \mathrm{O}_{6}, \mathrm{Li}_{6} \mathrm{Gd}\left(\mathrm{BO}_{3}\right)_{3}$ and $\mathrm{Li}_{2} \mathrm{~B}_{4} \mathrm{O}_{7}$ single crystals: pure and doped by cerium // Abstr. of 1999 Int. Confer. on Luminescence and Optical Spectroscopy of Condensed Matter. August 23-27, 1999. Osaka, Japan, P.68.

57. V.V. Antonov-Romanovsky, Kinetics of Crystal Luminophor Photoluminescence (in Russian), Moscow: Nauka, (1966).

58. I.N. Ogorodnikov, A.V. Porotnikov, S.V. Kudyakov et al., Stable and metastable optical absorption of non-linear $\mathrm{LiB}_{3} \mathrm{O}_{5}$ crystals (in Russian) // Fiz. Tverd. Tela 39(9), pp.1535-1537 (1997).

59. G.I. Malovichko, V.G. Grachev, A.O. Matkovskiy, EPR of the radiation-induced defects in neutron-irradiated lithium tetraborate single crystals (in Russian) // Fiz. Tverd. Tela 33(7), pp.1966-1972 (1991).

60. A.V. Porotnikov, I.N. Ogorodnikov, S.V. Kudyakov, A.V Kruzhalov et al., EPR of the hole center in non-linear $\mathrm{LiB}_{3} \mathrm{O}_{5}$ crystals (in Russian) // Fiz. Tverd. Tela 39(8), pp.1380-1383 (1997).

61. S.V. Gorbunov, K.N. Giniyatulin, A.V. Kruzhalov et al., Optical characteristics of $\mathrm{F}^{+}$-centers in beryllium oxide (in Russian) // Fiz. Tverd. Tela 28 (2), pp.606-608 (1986).

62. A.V. Kuznetsov, A.B. Sobolev, I.N. Ogorodnikov, A.V Kruzhalov, Simulation of the paramagnetic $\mathrm{B}^{2+}$ center in lithium triborate (in Russian) // Fiz. Tverd. Tela 36(12) pp.35303536 (1994).

63. V.G. Kostishin, L.M. Letyik, O.E. Bugakova, E.R. Senderson, Radiation-induced color centers in $\mathrm{Gd}_{2,6} \mathrm{Ca}_{0,4} \mathrm{Mg}_{0,25} \mathrm{Zr}_{0,65} \mathrm{Ga}_{4,1} \mathrm{O}_{12}$ single crystals (in Russian) // Neorgan. Mater. 33(7), pp. 853857 (1997).

64. Andrzej J. Wojtowicz, Scintillation mechanism: the significance of variable valence and electron-lattice coupling in R.E.-activated scintillators // Proc. SCINT-95. Netherlands, Delft: University Press, pp. 95-103 (1996). 